\title{
Vitamin C for the common cold should not be rejected on the basis of old and erroneous articles : [Letter]
}

\section{Hemilä, Harri}

2009

Hemilä , H 2009 , ' Vitamin C for the common cold should not be rejected on the basis of old and erroneous articles : [Letter] ' , Journal of Allergy and Clinical Immunology, vol. 124 , no. 4 , pp. 859-859 . https://doi.org/10.1016/j.jaci.2009.06.015

http://hdl.handle.net/10138/228310

https://doi.org/10.1016/j.jaci.2009.06.015

publishedVersion

Downloaded from Helda, University of Helsinki institutional repository.

This is an electronic reprint of the original article.

This reprint may differ from the original in pagination and typographic detail.

Please cite the original version. 


\section{Correspondence}

\section{Vitamin $\mathrm{C}$ for the common cold should not be rejected on the basis of old and erroneous articles}

\section{To the Editor:}

Mainardi et al ${ }^{1}$ reviewed the use and effects of complementary and alternative medicines on respiratory symptoms. They stated that early studies on vitamin $\mathrm{C}$ did not demonstrate an effect on the duration or intensity of the common cold, and as a support to this statement, they referred to 2 articles from $1975 .^{2,3}$

I showed a decade ago that the Karlowski trial was erroneously analyzed. ${ }^{4-6}$ The authors argued that the results of their placebocontrolled double-blind trial might be explained, paradoxially, by the placebo effect. However, their suggestion was based on a subgroup analysis in which they excluded $42 \%$ of recorded common cold episodes without any justification. In addition, there were logical inconsistencies in the explanation. Thus their placebo effect explanation can be confidently rejected. ${ }^{4-6}$ Karlowski et $\mathrm{al}^{2}$ had $4 \mathrm{arms}$ in their trial: A, placebo; B, $3 \mathrm{~g} / \mathrm{d}$ vitamin C regularly over the trial; $\mathrm{C}, 3 \mathrm{~g} / \mathrm{d}$ therapeutic vitamin $\mathrm{C}$ when a participant caught a cold; and $\mathrm{D}$, both regular and therapeutic administration so that the dose was $6 \mathrm{~g} / \mathrm{d}$ during the cold episodes. The results were consistent with dose dependency: the duration of colds in the $6 \mathrm{~g} / \mathrm{d}$ arm was reduced twice as much as in the $3 \mathrm{~g} / \mathrm{d}$ arms. In the $6 \mathrm{~g} / \mathrm{d}$ arm the common cold episodes were shortened by 1.22 days $(17 \%, P=.05)$, from 7.14 to 5.92 days. ${ }^{2,4}$

Dykes and Meier ${ }^{3}$ reviewed the early studies on vitamin $\mathrm{C}$ and the common cold. They discussed the technical aspects of certain studies, but in most cases they did not present the original results, thereby hampering the reader in drawing his or her own conclusions about the trial results. ${ }^{6,7}$ They uncritically accepted Karlowski et al's placebo effect explanation, ${ }^{2}$ although careful reading of the report would have shown that it is not valid. There are many further problems in the Dykes and Meier review, ${ }^{3}$ as described elsewhere. ${ }^{6,7}$

The coverage of Mainardi et al's review ${ }^{1}$ is wide, and they could not properly discuss the extensive literature on vitamin C and the common cold on the basis of original trial reports. Nevertheless, for a reader it would have been more useful to refer to an up-to-date review that covers also the trials carried out after 1975 and gives references to other recent literature ${ }^{8}$ instead of referring to 3-decade-old articles that have been shown to be erroneous 1 decade ago. There is firm evidence that regular vitamin $\mathrm{C}$ supplementation shortens the duration of colds that occur during the supplementation period, but the practical significance of this finding is not clear. ${ }^{8}$

Harri Hemilä, $M D, P h D$

From the Department of Public Health, University of Helsinki, Helsinki, Finland E-mail: harri.hemila@helsinki.fi.

Disclosure of potential conflict of interest: The author has declared that he has no conflict of interest.

\section{REFERENCES}

1. Mainardi T, Kapoor S, Bielory L. Complementary and alternative medicine: herbs, phytochemicals and vitamins and their immunologic effects. J Allergy Clin Immunol 2009;123:283-94.

2. Karlowski TR, Chalmers TC, Frenkel LD, Kapikian AZ, Lewis TL, Lynch JM. Ascorbic acid for the common cold: a prophylactic and therapeutic trial. JAMA $1975 ; 231: 1038-42$
3. Dykes MHM, Meier P. Ascorbic acid and the common cold: evaluation of its efficacy and toxicity. JAMA 1975;231:1073-9.

4. Hemilä H. Vitamin C, the placebo effect, and the common cold: a case study of how preconceptions influence the analysis of results. J Clin Epidemiol 1996;49:1079-87.

5. Hemilä H. Analysis of clinical data with breached blindness. Stat Med 2006;25: 1434-7.

6. Hemilä H. Do vitamins $\mathrm{C}$ and $\mathrm{E}$ affect respiratory infections? [PhD thesis]. Helsinki, Finland: University of Helsinki; 2006. p. 21-7, 42-5. Available at:http:// ethesis.helsinki.fi/julkaisut/laa/kansa/vk/hemila/. Accessed June 30, 2009.

7. Hemilä H. Vitamin C supplementation and common cold symptoms: problems with inaccurate reviews. Nutrition 1996;12:804-9.

8. Hemilä H, Douglas RM, Chalker EB, Treacy B. Vitamin C for preventing and treating the common cold. Cochrane Database Syst Rev 2007;(3):CD000980.

Available online August 6, 2009 doi:10.1016/j.jaci.2009.06.015

\section{Reply}

\section{To the Editor:}

Vitamin $\mathrm{C}$ is also known as L-ascorbic acid, dehydroascorbic acid, the antiscorbutic vitamin, L-xyloascorbic acid, and L-threohex-2-uronic acidy-lactone and was originally used by a 17th century East India Company ship's surgeon, Richard Woodall, who recommended the use of lemon juice as a preventive and cure of scurvy in his book Surgeon's Mate. It has been claimed by many as a cure-all for many diseases and problems, from cancer to the common cold. Since then, its biochemical properties have been well described, and its deficiency in the human population leads to predictable and well-known pathology.

The use of vitamin $\mathrm{C}$ in either preventing or ameliorating the symptoms or duration of any infection is beyond the scope of the review article and was mentioned only for historical interest. However, although several of the articles cited are more than 30 years old, they provide insight into the potential for vitamin C to act as an antioxidant and possibly decrease the intensity of an anti-inflammatory response to various stimuli. The first article ${ }^{1}$ referenced in our article included more than 300 participants in a placebo-controlled trial, with almost 200 completing the trial. The treatment group was given $1 \mathrm{~g}$ of vitamin $\mathrm{C} 3$ times a day, which by all accounts is a large dose. The data did show a trend toward vitamin C's effectiveness in decreasing the severity and duration of colds, but it was mild. The second ${ }^{2}$ article showed a similar trend toward the effectiveness of vitamin $\mathrm{C}$ but again with only mild efficacy. These trends are of historical importance. An updated Cochrane Review ${ }^{3}$ with an exhaustive look at more than 29 trials and 11,000 participants showed a nuanced effect of vitamin $\mathrm{C}$ in that there was again only a mild effect in the general population, with more impressive effects on persons exposed to physical stressors, such as exercise or cold weather. This nuanced effect continues when looking at the supplementation of vitamin C in elderly persons with acute respiratory tract infections ${ }^{4}$ and on the viral load of HIV-infected patients. ${ }^{5}$

However, with respect to this review article and its focus on asthma and allergy, the effect of vitamin $\mathrm{C}$ is much more moderate, and there exists a larger agreement among practitioners about its use in treating atopic disorders. The articles cited ${ }^{6-8}$ have demonstrated that there exists a correlation between serum levels of vitamin $\mathrm{C}$ and the severity of asthma, but no consensus yet exists on the supplementation with vitamin $\mathrm{C}$ and the treatment of the atopic disorders. Therefore its use as a supplement is not recommended for ameliorating conditions such as asthma, allergy, or 